Article

\title{
Employee Behaviors toward Using and Saving Energy at Work. The Impact of Personality Traits
}

\author{
Dawid Szostek
}

Citation: Szostek, D. Employee Behaviors toward Using and Saving Energy at Work. The Impact of Personality Traits. Energies 2021, 14, 3404. https://doi.org/10.3390/ en14123404

Academic Editor: Korjenic Azra

Received: 14 May 2021

Accepted: 8 June 2021

Published: 9 June 2021

Publisher's Note: MDPI stays neutral with regard to jurisdictional claims in published maps and institutional affiliations.

Copyright: (C) 2021 by the author. Licensee MDPI, Basel, Switzerland. This article is an open access article distributed under the terms and conditions of the Creative Commons Attribution (CC BY) license (https:/ / creativecommons.org/licenses/by/ $4.0 /)$.
Faculty of Economic Sciences and Management, University of Nicolaus Copernicus in Torun, Gagarina 13a, 87-100 Torun, Poland; dawidsz@umk.pl; Tel.: +48-611-48-81

\begin{abstract}
The purpose of the article is to determine how personality traits (extraversion, neuroticism, conscientiousness, agreeableness and openness to experience) affect organizational citizenship behaviors for the environment (OCBE), especially in the context of energy saving. The purpose is also to verify the hypothesis that this impact is significantly moderated by individuals' demographic characteristic (sex, age, length of service, work type and economic sector of employment). To achieve the purposes, a survey was conducted in 2020 on 454 working people from Poland. The analysis was based on structural equation modeling (SEM). The research model assumed that particular types of personality affect direct and indirect OCBEs, including energy-saving patterns. The model also included the aforementioned demographic characteristics of respondents. I proved that personality traits have a significant impact on direct and indirect organizational citizenship behaviors for the environment. In the case of direct OCBEs, the energy-saving items that were most significantly affected by employee personality were: I am a person who turns off my lights when leaving my office for any reason; I am a person who turns off the lights in a vacant room; I am a person who makes sure all of the lights are turned off if I am the last to leave. The strongest predicators were Neuroticism (negative relationship) and Agreeableness (positive relationship) for direct OCBE, but Extraversion (positive relationship) and Agreeableness (negative relationship) for indirect OCBE. The impact of an individual's personality on OCBE was significantly moderated mainly for indirect behaviors. This applied to all the analyzed demographic variables, but it was stronger for women, employees aged up to 40 years, those with 10 years or more experience, office/clerical workers, and public sector employees. The article discusses the theoretical framework, research limitations, future research directions and practical implications.
\end{abstract}

Keywords: energy saving in consumption; sustainable energy consumption; energy saving at work; green behaviors at work; organizational citizenship behaviors for the environment

\section{Introduction}

Nowadays, organizational focus on sustainability is very high and is set to grow in importance [1-6]. This results from growing social pressure, which is rooted in the awareness that human economic activity is responsible for large-scale degradation of the ecosystem $[4,7,8]$. Hence, almost every industry is implementing some sort of practice aimed at protecting the natural environment and increasing environmental awareness among employees [9]. Socially responsible investing is estimated to have already exceeded $10 \%$ of all company investments [10]. Furthermore, more than $80 \%$ of the 600 largest companies in the USA engage in sustainability initiatives (the average company undertakes 10 different initiatives per year) [8].

One important aspect of pro-environmental behaviors at work is energy saving, which is also referred to as "sustainable energy consumption" [11]. According to the United Nations sustainable development goals (SDG), it is important to "ensure access to affordable, reliable, sustainable and modern energy" (SDG 7), especially for poor countries. Furthermore, energy is a major contributor to climate change because energy production is responsible for 
about $60 \%$ of total gas emissions (see also SDG 13). That is why the world needs a green economy and green jobs that will maintain everyday sustainable practices in our private and professional lives alike [12].

Nevertheless, the majority of research on energy use and energy consumption patterns has concentrated on the domestic context $[13,14]$. Meanwhile, non-domestic facilities are responsible for about $25 \%$ of overall energy use [15]. Furthermore, according to Siero et al. [16] energy-saving behaviors cannot be generalized from the household to the workplace. In the first case, costs are paid privately, while an individual's benefits from energy saving at work are entirely indirect.

Over the past fifty years, many studies have focused on better understanding what constitutes pro-environmental behavior in organizations [17]. This is understood to be "behavior that consciously seeks to minimize the negative impact of one's actions on the natural and built world (e.g., minimize resource and energy consumption, use non-toxic substances, reduce waste production)" [17] (p. 240). Employees are key stakeholders, and their involvement in the process of greening an organization is a strategic capability. The process of organizational sustainability starts with the employee's decision to behave sustainably (employee green behaviors-EGB). It is not without reason that we increasingly hear of green (environmental) human resource management (green/environmental HRM), understood as "HRM activities, which enhance positive environmental outcomes" [18] (p. 1075). These activities include, among other things, recruitment practices (attracting individuals with similar environmental sensibility), rewarding (including environmental initiatives) and trainings (to develop ecological knowledge and skills) [5,9,19].

Green behaviors are not only formal activities (required, systemic, mandatory, e.g., installing systems to control contaminant emission), but also discretionary initiatives (those neither mandated nor rewarded), such as sorting waste, saving water, switching off unnecessary lights, reducing pollution, or proposing efficiencies in material consumption [3,4,19-21]. Required EGBs are behaviors performed within the context of job duties [3]. By contrast, discretionary acts suggest that the employee makes decisions autonomously without formal encouragement [4]. The nature of green behaviors in the workplace is complex, multiple and contingent, so they cannot be focused only on procedures, formal activities and reward practices-it is impossible to document all potential green behaviors $[4,20,21]$. For most employees, extra-role behaviors are not needed because they are, by definition, behaviors that go beyond the requirements of a given position [7].

The formal approach is more palliative, and the discretionary one either is preventive or compensates for the deficiencies of formal management systems [20]. Many authors have even claimed that such voluntary initiatives and daily private and work practices for improving environmental performance and saving energy (such as turning off lights or computers after work) are a condition for the success of systemic activities (e.g., ISO 14001 standard), and thereby also the process of organizational greening itself [5,19-22].

According to Daily et al. [22] (p. 3), "the success of important environmental programs may hinge on employee behavior that is beyond the scope of formal reward and performance evaluation systems" (see also [2]). Spontaneity of OCBEs can complement the formal environmental activity of an organization and allow employees to share their skills and knowledge, going beyond prescribed behaviors [23]. Even small employee efforts, such as printing double-sided, turning off lights in unoccupied rooms or saving paper towels, have a strong influence on organizational resource use and thus on the natural environment. OCBEs also require the sharing of tacit knowledge between employees, which can be understood as individual knowledge that is not so easy to codify and that is related to learning focused on activity and practice [20]. This knowledge is crucial in identifying sources of pollution in the organization [20].

However, little research has concentrated on the nature and role of citizenship behaviors in the literature of environmental management [22]. Much more attention has been focused on the organizational (explicit and formal) level of pro-environmental behaviors, such as green management [1]. 
It is also not clear how, concretely, OCBEs improve organizational performance for the environment, nor why those behaviors should be encouraged by supervisors [20,21]. Moreover, most studies do not distinguish between voluntary behaviors and behaviors based on compliance with organizational politics and procedures [5,21]. Hence, Boiral [20] indicates the arguments for why OCBEs are so important for research and practice: the environmental topics are differentiated, formal management has many limitations, the importance of tacit knowledge and helping behaviors in pro-environmental activities, social support and citizenship green behaviors.

Key to understanding the essence of environmental extra-role behaviors would appear to be an understanding of the main drivers (motivators) of activities that improve organizational environmental performance [21]. It may be stated that the determinants of such behaviors are very complex [17]. Insufficient research has been devoted to the conditions under which employees undertake extra-role green behaviors [2,3].

The lack of knowledge on how to support such behaviors means that they may be understood as merely indefinite, occasional and uncontrollable activities [20]. Although OCBEs are without formal reward systems, they are not only unprompted, but can also be a reaction to organizational coercion. This means that these behaviors can be encouraged by the organization and supervisors, who are very important to the development of OCBE [19]. Managers can promote a climate conducive to such discretionary proenvironmental initiatives [20], called a "green climate", which is understood as a "climate that applies to corporations that achieve sustainable objectives by implementing a range of proenvironmental policies" [5] (p. 616). This can be done through an appropriate organizational culture ("green culture"), pro-environmental programs, structures, trainings, informational and recruitment policies, etc. [5].

Norton et al. [3], in presenting an integrated multilevel model for EGB, divided the totality of factors conditioning OCBE into the contextual (law regulations, organizational policy, leadership style or team norms), e.g., and the personal (e.g., personality, attitudes, motivation, intentions). Relatively little attention is paid in the research to the contextual factors enabling OCBEs to manifest at the individual level [23]. There is also insufficient description of personal factors.

The literature on factors conditioning OCBE usually focuses on the role of:

- The supervisory (e.g., leader personality, management styles, sharing of a vision with employees) and its support (through resources, behaviors, communication, commitment, etc.) or perceived organizational support (POS) (or perceived supervisory support for the environment [PSS-E]);

- $\quad$ Social norms (policies, organizational values, organizational climate);

- Personal predisposition (demographic characteristics such as sex or years of education, personal values, moral norms, attitudes, habits, beliefs that environment is important, self-interest);

- $\quad$ Self-efficacy (confidence in own effectiveness); and

- Past behaviors or environmental stressors (perceived threats, e.g., air pollution) $[1,2,4,5,7,8,17,19,24-26]$.

Unfortunately, however, these are often nothing but theoretical digressions or a priori paradigms unsupported by reliable research results.

One unstudied area is the impact of personality traits on OCBEs, and another is the impact of demographic characteristics (sex, age, length of service, type of work, and economic sector of employment) on this relationship. Since such behaviors are discretionary, they can only be assumed to be more likely moderated by personality traits than by factors related to ability [27]. Only Dilchert [6] has addressed the impact of personality traits on volunteer green behaviors, though in relation to counterproductive sustainability behaviors (CSB). The author established that agreeable, conscientious and emotionally stable employees reported engaging in fewer CSBs. Conversely, neurotic individuals reported engaging in more CSBs. These relationships are very similar to the impact of individual personality on self-reported counterproductive work behaviors (CWB). 
The study is particular in applying an analysis of the relationship between personality and OCBE - and the moderators of this relationship - to the Polish cultural context. Cultural differences are significant enough that the results of such research can provide interesting conclusions [28].

In summary, bearing in mind the gaps in the current state of knowledge about the influence that personality traits have on OCBEs, the following objectives were set:

(1) To determine how employees' personality traits affect their intensity of engagement in organizational citizenship behaviors for the environment (with reference to direct and indirect OCBEs);

(2) To determine whether and how the influence of employee personality traits on their intensity of willingness to organizational citizenship behaviors for the environment is moderated by employee demographic characteristics (sex, age, length of service, type of work and economic sector of employment).

The objectives will be met with a survey conducted in March and April 2020 on a sample of 454 working people in Poland. These people were employed in various production, delivery and distribution companies, among others (and in various actors in a specific supply chain). Two hypotheses were adopted (see Figure 1):

Hypothesis 1 (H1). Personality traits of employees have a significant influence on the degree of organizational citizenship behaviors for the environment (related to direct and indirect OCBEs).

Hypothesis 2 (H2). The influence that employee personality traits have on the degree of organizational citizenship behaviors for the environment is impacted by the demographic characteristic of employees: (H2a) sex, (H2b) age, (H2c) length of service, (H2d) type of work and (H2e) economic sector of employment.

This article makes an important contribution to the theory in two fields. First, it reliably describes the impact of personality traits on the degree of engagement in OCBE (both direct and indirect), including in the field of energy saving. According to the abovementioned literature, daily sustainable energy-using practices in private and work life are very important and contribute to the greening of the whole economy. Therefore, it seems to be crucial to understand how those behaviors are influenced by the personality of employees. Furthermore, the author assumed that this impact is moderated by some significant demographic features of employees (sex, age, length of service, type of work, or economic sector of employment). The article comprises the following sections: theoretical framework, methodology of own research, discussion of results, contributions of the findings, limitations, future research directions and practical implications. 


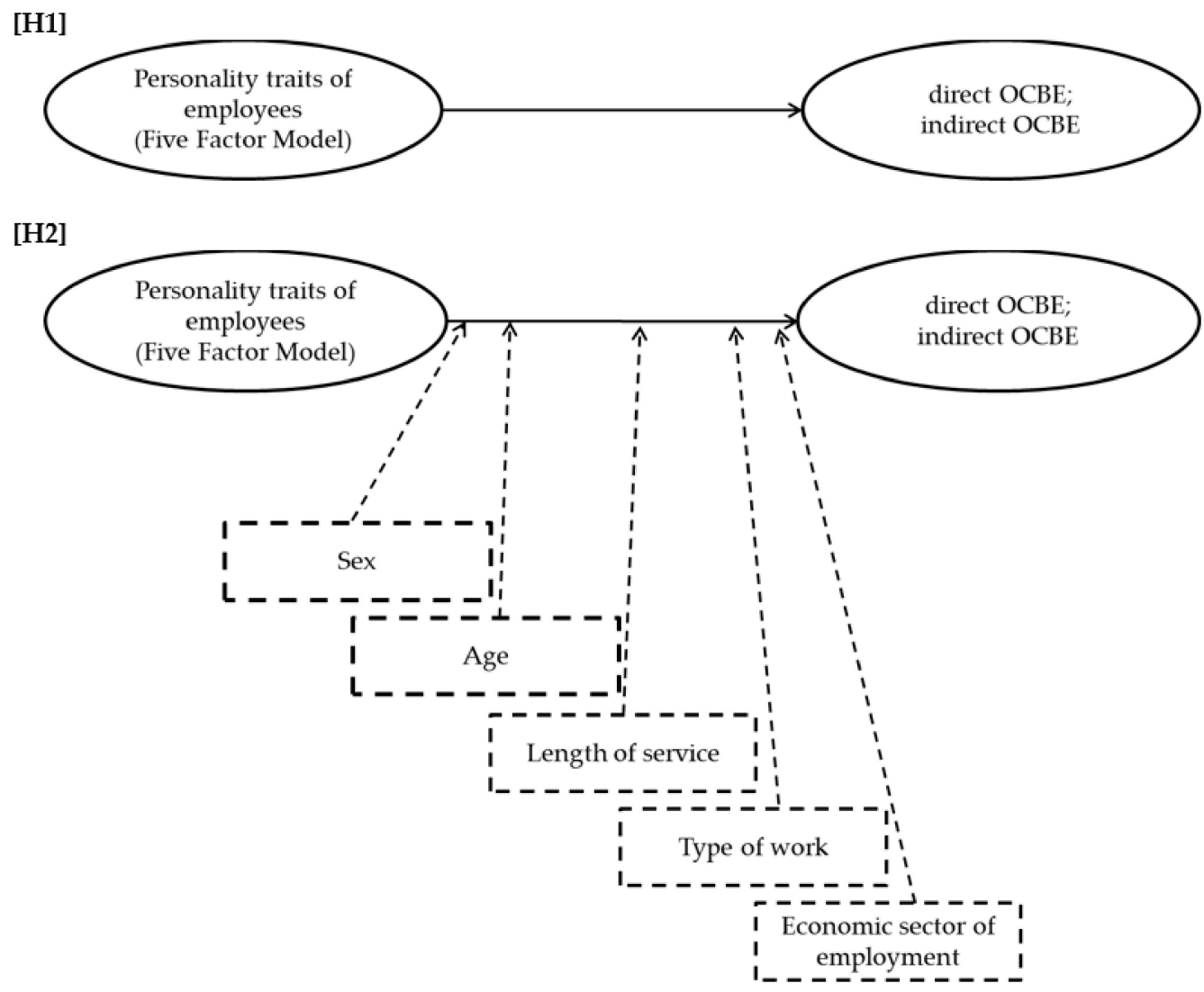

Figure 1. Visualization of hypotheses. Source: author's elaboration.

\section{Personality Traits}

The term "personality" is understood as "an individual's tendency to think, feel, and act in certain consistent ways" [29] (p. 497). The measurement of personality traits is common practice in many organizations, both in recruitment and during employment [30].

The literature has confirmed the usefulness of personality traits, including for explaining the behaviors and various forms of activity of humans, both in private life (e.g., [31,32]) and at work (e.g., $[29,33,34])$. Therefore, personality traits can also be helpful in understanding organizational citizenship behaviors, including for the environment.

Significantly, in many studies on personality, traits were found to be similar across different characteristics such as sex, age, culture and language (e.g., $[35,36])$. There is also evidence that personality traits are stable across time (e.g., [37]).

Some authors are skeptical that the influence of personality traits on employee behavior can be measured, arguing (unfortunately rightly) that there are methodological shortcomings to such research and a lack of reliable measurement instruments. However, in recent years, many validated personality models and instruments for measuring personality traits have appeared in circulation, making these reservations now obsolete [29].

The most studied and empirically tested model of personality is the Five Factor Model (FFM), called also "the Big Five" or OCEAN model, proposed by Costa and McCrae [38]. This model contains five categories (each consisting of six specific personality traits) that can be used to research the influence of personality on OCBE [27,39]:

- Extraversion (sociability, talkativeness, engagement with the external world),

- Conscientiousness (constraint)—conscientious individuals are reliable and dutiful, follow rules, and are pragmatic. Such employees spend more time on tasks, their knowledge is higher, they go beyond role requirement (OCB) and they avoid CWB [40],

- Emotional stability /neuroticism (negative affectivity)—lack of emotional stability, pessimism, anxiety. People high in neuroticism are more prone to withdrawal behaviors, 
whereas employees low in negative affectivity are optimistic and enthusiastic, and experience lower levels of anxiety,

- Agreeableness-people high in agreeableness are empathic and cooperative; disagreeable people are egotistical, self-centered, non-cooperative, manipulative, emotional and confrontational,

- Openness to experience (intellect/unconventionality)—individuals open to experience are more interested in various areas, imaginative and worldly.

Critics of FFM (e.g., [41,42]) claim that this model provides too simplified an image of personality. In truth, of the five traits, two are clarified in more detail, namely extraversion and emotional stability [43]. Thus, according to Briggs [44], no one has proved that precisely these five traits best explain personality.

The HEXACO model is proposed as an alternative to FFM. This is an acronym for six categories of personality, with the new one being honesty-humility, which includes willingness to exploit other people [45]. The sixth component of personality has been confirmed in studies conducted in Dutch, French, German, Hungarian, Italian, Korean, Polish and English [46]. Some authors believe (e.g., [46]) that this model is better in explaining the validity of overt integrity (honesty) tests, whereas the FFM better fits personality-based honesty tests. Integrity tests serve to establish job-candidate or employee propensity to engage in CWB.

\section{Organizational Citizenship Behaviors}

Contextual extra-role behaviors "refers to the discretionary, pro-social actions of individuals in the work context and sometimes beyond it-as when people represent their company positively to outsiders" [4] (p. 124). One manifestation of such behaviors is organizational citizenship behavior, which is understood as "individual behavior that is discretionary, not directly or explicitly recognized by the formal reward system, and that in the aggregate promotes the effective functioning of the organization" [47] (p. 4) or as "voluntary initiatives not explicitly required in the definition of job responsibilities that contribute to the improvement of organizational functioning" [20] (p. 222). The classic division includes two types of OCBs: OCB-O (behavior directed at the organization, e.g., caring for the good name of the company) and OCB-I (behavior directed towards other individuals, e.g., selflessly helping a work colleague).

To distinguish OCB from other similar concepts (e.g., [48-50]), Organ assumed that OCBs are "contributions to the maintenance and enhancement of the social and psychological context that support task performance" [51] (p. 91). So, summarizing, OCBs are behaviors that are: not part of the job description, beneficial to the employer, conducted without expectation of reward, and motivated by the need to help the organization [52].

These behaviors have been considered in many studies since the end of the 1990s [20]. The research in this field concentrates primarily on the antecedents, expressions and practical implications of OCBs. Extra-role behaviors are an important dimension of job performance and supporting them is very important in order to increase individual and organizational productivity. Many authors have evidenced that the efficiency of an organization may largely depend on voluntary, unrewarded behaviors, including helping others, involvement in the unofficial life of the organization, personal development activities, improvement initiatives, or building a positive corporate image [21]. This is so because formal behaviors at work represent a part (not necessarily the majority) of possible individual actions [53].

There are many classifications of $\mathrm{OCB}$, but the most cited is the taxonomy developed by Organ et al. [53], with such categories as: helping (spontaneous altruism and collaboration), sportsmanship (acceptance of organizational obstacles), organizational loyalty (building the company's good name and respecting organizational goals), organizational compliance (adherence to organizational values, policies and rules), individual initiative (personal involvement) and self-development (the non-obligatory raising of qualifications and skills, to the advantage of the organization). Some of these dimensions (mainly altruism and 
courtesy) are well described and measured, and others are less studied and still being operationalized [54]. Different classifications regarding OCB have been proposed by Podsakoff et al., 2000 and by Spector and Fox [55].

\section{Discretionary Behaviors for the Environment}

Much research on OCB focuses on understanding the causes and manifestations of such behavior and its impact on organizational development. However, previous studies have ignored the broader environmental context, focusing more closely instead on anthropocentric and intra-organizational perspectives. The benefits of such behaviors for the wider group of external stakeholders and nature have also not been addressed [20]. Meanwhile, each of the mentioned OCB categories [53] benefits not only the organization and employees, but also society and the ecosystem.

Environmental OCBs (OCBE) are bound to OCBs (e.g., [2,20]), but the two constructs are separate. OCBEs are focused neither on the organization nor on the individual, but on the broader surroundings in which the organization functions [2]. The significance of OCBEs may have been overlooked precisely because the behaviors are not concentrated on individuals but on the environment, and are thus anonymous, less visible and less conspicuous, making them also more difficult to recognize [20]. Table 1 presents some definitions of OCBE.

Table 1. Selected definitions of OCBE.

\begin{tabular}{|c|c|}
\hline Author(s) & Definition of OCBE \\
\hline [20] (p. 223) & $\begin{array}{l}\text { "Individual and discretionary social behaviors that are not explicitly } \\
\text { recognized by the formal reward system and that contribute to a more } \\
\text { effective environmental management by organizations." }\end{array}$ \\
\hline [22] (p. 246) & $\begin{array}{l}\text { "Discretionary acts by employees within the organization not rewarded } \\
\text { or required that are directed toward environmental improvement." }\end{array}$ \\
\hline [2] (p. 163) & $\begin{array}{l}\text { "Voluntary behavior not specified in official job descriptions that, } \\
\text { through the combined efforts of individual employees, help to make the } \\
\text { organization and/or society more sustainable." }\end{array}$ \\
\hline [19] (p. 3553) & $\begin{array}{l}\text { "Individual discretionary behaviors that supplement formal EMPs } \\
\text { [environmental management practices-D. Sz.] and contribute to the } \\
\text { efficiency of environmental measures." }\end{array}$ \\
\hline [3] (p. 105) & $\begin{array}{l}\text { "Employee green behavior involving personal initiative that exceeds } \\
\text { organizational expectations. This includes prioritizing environ-mental } \\
\text { interests, initiating environmental programs and policies, lobbying and } \\
\text { activism, and encouraging others. The concept of voluntary EGB aligns } \\
\text { closely with the notions of contextual performance and organizational } \\
\text { citizenship behavior, which refer to behaviors that support the } \\
\text { organizational, social and psychological environment in which task } \\
\text { performance takes place." }\end{array}$ \\
\hline
\end{tabular}

Source: author's elaboration.

Though the term "organizational citizenship behavior for the environment" is the most cited in the literature, these behaviors are also referred to as environmental citizenship behaviors (ECB), conservation behaviors, pro-environmental behaviors (PEB), environmentally significant behaviors, environmentally sustainable behaviors, proactive green behaviors, environmentally friendly behaviors, environmental workplace behaviors, or responsible environmental behaviors $[1,2,4,5,56]$. These behaviors have many diverse manifestations, though the measuring and validating of this construct has not been well explored [21]. The difficulties in measurement stem mainly from the nature of such initiatives, which are discretionary and informal (so-called silent variables). This is also why the literature is dominated by theoretical studies concentrating on the scope, determinants and impacts of such behaviors. This concept is not well established [2], because there is a lack 
of validated measurement instruments; this is also true of the concept of counterproductive sustainability behaviors (e.g., [6]).

Not every pro-environmental involvement of employees and environmental commitment of an organization qualifies as an OCBE [4]. These behaviors differ from general sustainable behaviors in private or professional lives. Above all, OCBEs are proactive behaviors that employees perform in organizational settings. Moreover, these behaviors are not necessary for the functioning of an employee, but they imply a set of activities that can help solve environmental problems in the long term. Thirdly, OCBEs are undertaken with the environment in mind, while helping the organization is a side-effect. Lastly, there are no extrinsic rewards for these behaviors [2].

There are several conditions for maximizing the benefits of OCBE [21]:

- Individual champions/leaders are needed who are understood to be, not experts in the field of environmental protection, but people who care about ecological issues and whose initiative can encourage others to act likewise;

- Eco-innovations are the outcome of individual minds and tips;

- Reducing pollution in the organization is difficult without employee involvement in formal procedures, but also in voluntary behaviors addressing pollution in the workplace;

- Successful implementation of environmental management systems requires employee involvement.

Exploring the nature and scope of voluntary environmental behaviors of employees, Boiral [20] based his work on five of the six categories of OCBs (without organizational compliance) proposed by Organ et al. [53]:

1. Helping-altruistic pro-environmental behaviors (e.g., supporting other employees in acting pro-environmentally, collaborating on environmental initiatives, promoting such initiatives, etc.);

2. Sportsmanship - engaging in extra work that can have positive environmental outcomes (e.g., segregating or recycling waste, etc.);

3. Organizational loyalty—supporting sustainable policy and tasks (e.g., promoting the company's pro-environmental activities among stakeholders, representing the company at eco-events, etc.);

4. Individual initiative-taking part in pro-environmental acts (sharing information and knowledge about ecological solutions, suggestions on pollution prevention, proposing ecological innovations, etc.);

5. Self-development-increasing knowledge and acquiring skills, which facilitates the improved solving of environmental problems, participation in training for sustainable development (e.g., on green technologies), etc.

Meanwhile, Boiral and Paillé [21], also citing Organ et al. [53], proposed a validated instrument for measuring OCBE based on three categories:

1. Eco-initiatives-defined as "discretionary behaviors or suggestions that are not recognized by the formal reward system and that cumulatively help to improve the organization's environmental practices or performance" [21] (p. 438) captured by three items: (1) In my work, I weigh the consequence of my actions before doing something that could affect the environment; (2) I voluntarily carry out environmental actions and initiatives in my daily work activities; (3) I make suggestions to my colleagues about ways to protect the environment more effectively, even when it is not my direct responsibility;

2. Eco-civic engagement-this category refers to the organizational loyalty and selfdevelopment by Organ et al. [53] and it means "voluntary and unrewarded participation in environmental activities that have been instituted by the organization and that contribute to improving its image or practices" [21] (p. 438). It is encapsulated by four items: (1) I actively participate in environmental events organized in and/or by my company; (2) I stay informed of my company's environmental initiatives; (3) I undertake en- 
vironmental actions that contribute positively to the image of my organization; (4) I volunteer for projects, endeavors or events that address environmental issues in my organization;

3. Eco-helping-this is understood as "voluntary and unrewarded behaviors aimed at helping colleagues to better integrate environmental concerns in the workplace" [21] (p. 438). This category is encapsulated by three items: (1) I spontaneously give my time to help my colleagues take the environment into account in everything they do at work; (2) I encourage my colleagues to adopt more environmentally conscious behavior; (3) I encourage my colleagues to express their ideas and opinions on environmental issues.

As the authors themselves note, the proposed items are very general in nature and tend to relate to behaviors that affect the environment indirectly. The authors provide more precise examples of behaviors within each of the categories (e.g., help to reduce paper use; place recyclable materials in the proper container), although many of them do not necessarily indicate volunteer behaviors, which is an essential quality of OCBEs (e.g., contribute to the annual sustainability report; participate in a green committee).

Homburg and Stolberg [25] distinguished indirect and direct engagement in proenvironmental behaviors in the workplace. These behaviors are direct when employees engage personally in activities that help avoid waste or unnecessary use of resources, and that reduce pollution. The direct pro-environmental behaviors include first of all recycling, reusing, and reducing [6]. Pro-environmental behaviors are indirect when employees lead other individuals in the organization to perform OCBE.

There are yet other proposed instruments for measuring OCBE, though these are mostly not validated, of which at least the seven-item scale by Kim et al., [9] should be mentioned.

\section{Materials and Methods}

\subsection{Sampling Procedures and Participant Characteristics}

The data was collected in March 2020 using an online internet survey. Of the full 468 questionnaires that were received in response, the 454 correctly filled out ones were analyzed (the author eliminated 14 questionnaires after checking cases of conflicting answers and careless compilation). Measurement was of professionally active people in Poland. There were no rewards or incentives offered to participants. It is not possible to establish the percentage of respondents who answered the questionnaire, because the sample selection was non-random. The invitation to complete the questionnaire was sent to:

- $\quad$ The public sector in Poland (about 2500 organizations);

- The companies listed in "Wprost" weekly's 2018 ranking of 200 largest companies in Poland (http:/ / rankingi.wprost.pl/200-najwiekszych-firm\#pelna-lista; (accessed on 29 June 2020);

Respondents' demographic characteristics are presented in Table 2. 
Table 2. Demographic characteristics of the sample.

\begin{tabular}{|c|c|c|c|c|c|}
\hline \multirow{3}{*}{ Sex } & $\mathrm{F}$ & $75.1 \%$ (341 persons) & \multirow{4}{*}{$\begin{array}{c}\text { Current Work } \\
\text { Type }\end{array}$} & office/clerical & $72.5 \%(329)$ \\
\hline & M & $24.7 \%(112)$ & & management & $26.9 \%(122)$ \\
\hline & $\mathrm{n} / \mathrm{a}$ & $0.2 \%(1)$ & & blue collar & $0.4 \%(2)$ \\
\hline \multirow{5}{*}{ Age } & mean & 42.03 years & & $\mathrm{n} / \mathrm{a}$ & $0.2 \%(1)$ \\
\hline & MIN & 20 years & \multirow{9}{*}{$\begin{array}{l}\text { Region of Poland } \\
\text { (Voivodship) }\end{array}$} & Dolnośląskie & $4.8 \%(22)$ \\
\hline & MAX & 67 years & & $\begin{array}{l}\text { Kujawsko- } \\
\text { Pomorskie }\end{array}$ & $10.13 \%(46)$ \\
\hline & SD & 9.84 years & & Lubelskie & $3.74 \%(17)$ \\
\hline & $\mathrm{n} / \mathrm{a}$ & 14 persons & & Lubuskie & $2.20 \%(10)$ \\
\hline \multirow{6}{*}{ Education } & higher & $90.5 \%(411)$ & & Łódzkie & $6.17 \%(28)$ \\
\hline & secondary & $8.6 \%(39)$ & & Małopolskie & $6.61 \%(30)$ \\
\hline & middle school & $0.4 \%(2)$ & & Mazowieckie & $10.79 \%(49)$ \\
\hline & none & $0.2 \%(1)$ & & Opolskie & $2.42 \%(11)$ \\
\hline & $\mathrm{n} / \mathrm{a}$ & $0.2 \%(1)$ & & Podkarpackie & $9.03 \%(41)$ \\
\hline & mean & 12.94 years & & Podlaskie & $6.61 \%(30)$ \\
\hline \multirow{4}{*}{$\begin{array}{l}\text { Length of } \\
\text { Service }\end{array}$} & MIN & 1 year & & Pomorskie & $8.37 \%(38)$ \\
\hline & MAX & 52 years & & Śląskie & $2.86 \%(13)$ \\
\hline & SD & 10.83 years & & Świętokrzyskie & $3.74 \%(17)$ \\
\hline & $\mathrm{n} / \mathrm{a}$ & 11 persons & & $\begin{array}{l}\text { Warmińsko- } \\
\text { Mazurskie }\end{array}$ & $7.05 \%(32)$ \\
\hline \multirow{3}{*}{$\begin{array}{c}\text { Sector of } \\
\text { Current } \\
\text { Employment }\end{array}$} & public & $54.8 \%(249)$ & & Wielkopolskie & $13.22 \%(60)$ \\
\hline & private & $44.7 \%(203)$ & & \multirow{2}{*}{\multicolumn{2}{|c|}{ Zachodniopomorskie $2.20 \%$ (10 persons) }} \\
\hline & $\mathrm{n} / \mathrm{a}$ & $0.4 \%(2)$ & & & \\
\hline
\end{tabular}

\subsection{Measurement Scales}

OCBEs were measured according to a scale based on the following two scales (see Appendix A): a 12-item scale by Lamm et al. [2] for direct OCBEs; and a 10-item scale by Boiral and Paillé [21] for indirect OCBEs. Both scales have been validated by their authors, besides which, there are currently few alternatives for measuring OCBE. Because there is no Polish version of these scales, the author translated them into Polish in collaboration with an English native speaker.

Inventories for measuring personality traits can be divided into Criterion-Focused Occupational Personality Scales (COPS) and Job-Focused Occupational Personality Scales (JOPS) [57]. The study used the IPIP-NEO-FFI-50 universal scale (International Personality Item Pool NEO-Five Factor Inventory-50), proposed by Goldberg [58]. This scale consists of 50 items divided into five factors-personality types (called "the Big Five"): Neuroticism, Extraversion, Openness to experience, Agreeableness and Conscientiousness (see Appendix B). The Polish version of this scale validated by Strus et al. [59] was used. This scale is based on the Big Five, which has been confirmed using various measurement instruments and in various communities and cultures (e.g., [60-62]). This model is widely accepted in explaining the structure of personality (e.g., [63]), as well as in research on how personality traits influence human behavior [64].

\section{Results}

\subsection{Reliability Values}

The author collected 454 correctly completed questionnaires, which were analyzed with IBM SPSS Statistics and IBM SPSS Amos v. 16 (IBM Corporation; Armont, NY, USA). 
Confirmatory factor analysis allowed the variables that most significantly shaped a given construct and had the highest factor loadings to be selected from those constituting the personality types and OCBE behavior categories. This was important from the perspective of the Structural Equation Model (SEM) that was later estimated. Table 3 presents individual factors (personality types and OCBE categories) and lists the observable variables shaping them ( $\mathrm{P}-$ personality traits; $\mathrm{O}-\mathrm{OCBE}$; the number alongside the variable corresponds to the number from the measurement scale—see Appendices A and B).

Table 3. Factors with measurable variables describing them and calculated with Cronbach's alpha statistics.

\begin{tabular}{ccc}
\hline Factor (Category/Trait) & Measurable Variables (Components) & Cronbach's Alpha \\
\hline Neuroticism & P16, P21, P31, P36, P41 & 0.763 \\
Extraversion & P7, P17, P27, P37, P47 & 0.795 \\
Openness to experience & P18, P23, P28, P33, P43 & 0.720 \\
Agreeableness & P9, P29, P39, P44, P49 & 0.743 \\
Conscientiousness & P20, P30, P35, P40, P50 & 0.794 \\
Direct OCBE & O1, O4, O7, O8, O12 & 0.860 \\
Indirect OCBE & O14, O15, O17, O18, O21 & 0.919 \\
\hline
\end{tabular}

Source: Author's own research results.

For most of the analyzed factors, Cronbach's alpha values ranged around 0.7 or higher, indicating the good reliability of the scale used.

In order to verify the hypotheses regarding, on the one hand, the impact of personality on the categories of OCBE behavior and, on the other, the moderation of this impact by demographic variables (including sex, age, length of service, type of work and economic sector of employment), two SEMs were estimated by maximum likelihood method. A significance level of 0.05 was applied to the models.

\subsection{Hypothesis Testing}

Hypothesis 1 (H1). Personality traits of employees have a significant influence on the degree of organizational citizenship behaviors for the environment (with reference to direct and indirect OCBEs).

The SEM model is presented schematically in Figure 2. This is a hypothetical model adopted to establish the structural relationships between personality traits and both categories of OCBEs. It also assumes the existence of relationships between personality traits themselves, without specifying direction of influence. In the model, these variables are the same as those listed in Table 3.

Table 4 contains the results of the maximum likelihood estimation of the external SEM (factor analysis), Table 5 shows the results of the same for the internal model (regression analysis), and Table 6 presents the values included in the correlation and covariance model. Table 7 also shows measurements of the model's fit to the data. 


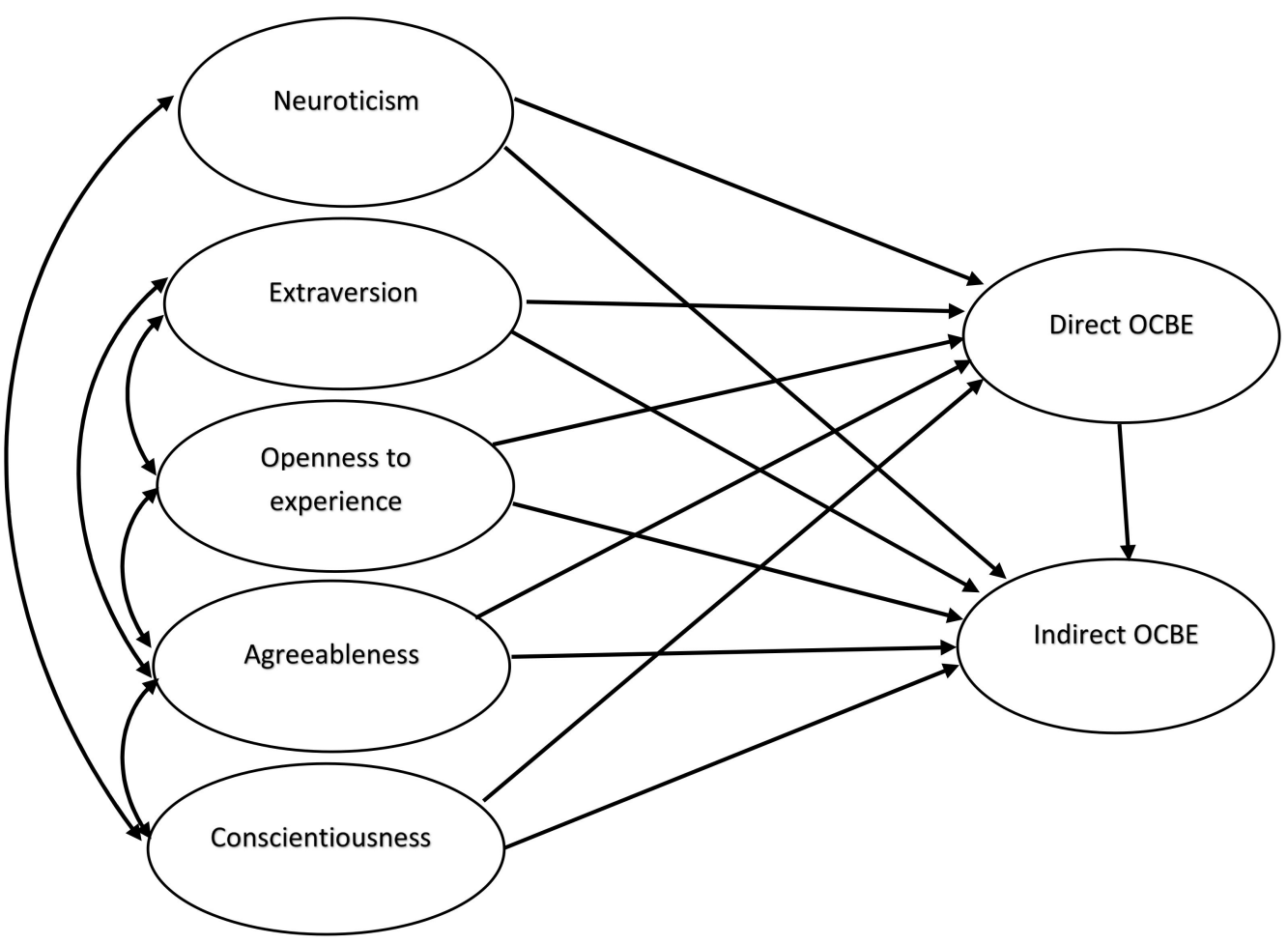

Figure 2. Schematic diagram of SEM model (influence of personality types on OCBE categories). Source: author's own work.

Table 4. Results of external SEM model estimation.

\begin{tabular}{|c|c|c|c|}
\hline Relationship & Parameter & Evaluation of Parameter & $p$ Value \\
\hline $\mathrm{P} 16 \leftarrow$ Neuroticism & $\alpha_{1}$ & 0.723 & 0.000 \\
\hline $\mathrm{P} 21 \leftarrow$ Neuroticism & $\alpha_{2}$ & 0.585 & 0.000 \\
\hline $\mathrm{P} 31 \leftarrow$ Neuroticism & $\alpha_{3}$ & 0.734 & 0.000 \\
\hline P36 $\leftarrow$ Neuroticism & $\alpha_{4}$ & 0.727 & 0.000 \\
\hline $\mathrm{P} 41 \leftarrow$ Neuroticism & $\alpha_{5}$ & 0.416 & - \\
\hline $\mathrm{P} 7 \leftarrow$ Extraversion & $\alpha_{6}$ & 0.714 & 0.000 \\
\hline $\mathrm{P} 17 \leftarrow$ Extraversion & $\alpha_{7}$ & 0.606 & 0.000 \\
\hline $\mathrm{P} 27 \leftarrow$ Extraversion & $\alpha_{8}$ & 0.726 & 0.000 \\
\hline $\mathrm{P} 37 \leftarrow$ Extraversion & $\alpha_{9}$ & 0.628 & 0.000 \\
\hline $\mathrm{P} 47 \leftarrow$ Extraversion & $\alpha_{10}$ & 0.647 & - \\
\hline $\mathrm{P} 18 \leftarrow$ Openness to experience & $\alpha_{11}$ & 0.588 & 0.000 \\
\hline $\mathrm{P} 23 \leftarrow$ Openness to experience & $\alpha_{12}$ & 0.599 & 0.000 \\
\hline P28 $\leftarrow$ Openness to experience & $\alpha_{13}$ & 0.505 & 0.000 \\
\hline $\mathrm{P} 33 \leftarrow$ Openness to experience & $\alpha_{14}$ & 0.591 & 0.000 \\
\hline $\mathrm{P} 43 \leftarrow$ Openness to experience & $\alpha_{15}$ & 0.604 & - \\
\hline P9 $\stackrel{1}{\leftarrow \text { Agreeableness }}$ & $\alpha_{16}$ & 0.511 & - \\
\hline P29 $\leftarrow$ Agreeableness & $\alpha_{17}$ & 0.558 & 0.000 \\
\hline P39 $\leftarrow$ Agreeableness & $\alpha_{18}$ & 0.798 & 0.000 \\
\hline $\mathrm{P} 44 \leftarrow$ Agreeableness & $\alpha_{19}$ & 0.537 & 0.000 \\
\hline P49 $\leftarrow$ Agreeableness & $\alpha_{20}$ & 0.670 & 0.000 \\
\hline $\mathrm{P} 20 \leftarrow$ Conscientiousness & $\alpha_{21}$ & 0.649 & 0.000 \\
\hline P30 $\leftarrow$ Conscientiousness & $\alpha_{22}$ & 0.727 & 0.000 \\
\hline P35 $\leftarrow$ Conscientiousness & $\alpha_{23}$ & 0.576 & 0.000 \\
\hline P40 $\leftarrow$ Conscientiousness & $\alpha_{24}$ & 0.708 & 0.000 \\
\hline P50 $\leftarrow$ Conscientiousness & $\alpha_{25}$ & 0.631 & - \\
\hline $\mathrm{O} 1 \leftarrow$ Direct OCBE & $\alpha_{26}$ & 0.665 & - \\
\hline $\mathrm{O} 4 \leftarrow$ Direct OCBE & $\alpha_{27}$ & 0.748 & 0.000 \\
\hline $\mathrm{O} 7 \leftarrow$ Direct OCBE & $\alpha_{28}$ & 0.833 & 0.000 \\
\hline $\mathrm{O} 8 \leftarrow$ Direct OCBE & $\alpha_{29}$ & 0.825 & 0.000 \\
\hline $\mathrm{O} 12 \leftarrow$ Direct OCBE & $\alpha_{30}$ & 0.666 & 0.000 \\
\hline
\end{tabular}


Table 4. Cont.

\begin{tabular}{cccc}
\hline Relationship & Parameter & Evaluation of Parameter & $p$ Value \\
\hline O14 $\leftarrow$ Indirect OCBE & $\alpha_{31}$ & 0.866 & 0.000 \\
O15 $\leftarrow$ Indirect OCBE & $\alpha_{32}$ & 0.882 & - \\
O17 $\leftarrow$ Indirect OCBE & $\alpha_{33}$ & 0.803 & 0.000 \\
O18 $\leftarrow$ Indirect OCBE & $\alpha_{34}$ & 0.900 & 0.000 \\
O21 $\leftarrow$ Indirect OCBE & $\alpha_{35}$ & 0.715 & 0.000 \\
\hline
\end{tabular}

Source: Author's own research results.

Table 5. Results of internal SEM model estimation.

\begin{tabular}{|c|c|c|c|c|}
\hline Relationship & Parameter & Evaluation of Parameter & $\begin{array}{c}\text { Evaluation of Standardized } \\
\text { Parameters }\end{array}$ & $p$-Value \\
\hline Neuroticism $\rightarrow$ Direct OCBE & $\beta_{1}$ & -0.633 & -0.391 & 0.000 \\
\hline Extraversion $\rightarrow$ Direct OCBE & $\beta_{2}$ & -0.261 & -0.195 & 0.022 \\
\hline Openness to experience $\rightarrow$ Direct OCBE & $\beta_{3}$ & 0.158 & 0.114 & 0.132 \\
\hline Agreeableness $\rightarrow$ Direct OCBE & $\beta_{4}$ & 0.333 & 0.197 & 0.034 \\
\hline Conscientiousness $\rightarrow$ Direct OCBE & $\beta_{5}$ & -0.129 & -0.111 & 0.161 \\
\hline Neuroticism $\rightarrow$ Indirect OCBE & $\beta_{6}$ & 0.331 & 0.131 & 0.073 \\
\hline Extraversion $\rightarrow$ Indirect OCBE & $\beta_{7}$ & 0.638 & 0.304 & 0.000 \\
\hline Openness to experience $\rightarrow$ Indirect OCBE & $\beta_{8}$ & 0.331 & 0.152 & 0.021 \\
\hline Agreeableness $\rightarrow$ Indirect OCBE & $\beta_{9}$ & -0.513 & -0.194 & 0.018 \\
\hline Conscientiousness $\rightarrow$ Indirect OCBE & $\beta_{10}$ & 0.197 & 0.109 & 0.114 \\
\hline Direct OCBE $\rightarrow$ Indirect OCBE & $\beta_{11}$ & 0.902 & 0.576 & 0.000 \\
\hline
\end{tabular}

Source: Author's own research results.

Table 6. Values of correlations and covariances included in SEM.

\begin{tabular}{ccccc}
\hline Relationship & Parameter & Covariance & Correlation & $p$-Value \\
\hline Neuroticism $\leftrightarrow$ Conscientiousness & $\pi_{1}$ & -0.192 & -0.618 & 0.000 \\
\hline Extraversion $\leftrightarrow$ Openness to experience & $\pi_{2}$ & 0.151 & 0.485 & 0.000 \\
\hline Openness to experience $\leftrightarrow$ Agreeableness & $\pi_{3}$ & 0.132 & 0.533 & 0.000 \\
\hline Extraversion $\leftrightarrow$ Agreeableness & $\pi_{4}$ & 0.168 & 0.054 & 0.000 \\
\hline Agreeableness $\leftrightarrow$ Conscientiousness & $\pi_{5}$ & 0.027 & 0.034 \\
\hline
\end{tabular}

Source: Author's own research results.

Table 7. Measures of SEM fit.

\begin{tabular}{ccccc}
\hline Model & IFI & PNFI & RMSEA & CMIN/DF \\
\hline Estimated & 0.822 & 0.660 & 0.072 & 3.348 \\
Saturated & 1 & 0.000 & & \\
Independent & 0 & 0.000 & 0.158 & 12.238 \\
\hline
\end{tabular}

Source: Author's own research results.

The results for the external model (see Table 4) indicate that all factor loadings are statistically significant. For some parameters, no $p$-value is given, as it could not be calculated [65].

It should be noted (see Table 2) that Conscientiousness has no significant effect on either direct $\left(\beta_{5}\right)$ or indirect $\left(\beta_{10}\right)$ OCBE. The influences of Neuroticism on indirect OCBE $\left(\beta_{6}\right)$ and Openness to experience on direct $\operatorname{OCBE}\left(\beta_{3}\right)$ were also statistically insignificant. Extraversion is significantly favorable to indirect $\mathrm{OCBE}\left(\beta_{7}\right)$, while also reducing propensity for direct OCBE $\left(\beta_{2}\right)$. Agreeableness has exactly the opposite direction of influence, increasing propensity for direct OCBE $\left(\beta_{4}\right)$ and reducing propensity for indirect OCBE $\left(\beta_{9}\right)$. Neurotic individuals tend less towards direct OCBE $\left(\beta_{1}\right)$, while individuals high in 
openness to experience tend more likely towards indirect OCBE $\left(\beta_{8}\right)$. Importantly, direct OCBEs are statistically significantly conducive to the formation of indirect OCBEs $\left(\beta_{11}\right)$.

The correlations between personality traits (see Table 6) are all statistically significant. Moreover, only the relationship between Neuroticism and Conscientiousness is negative, while the rest of the relationships are positive.

The model fits the empirical data (see Table 7): the IFI (Incremental Fit Index-the range of value: $\langle 0 ; 1\rangle$, the higher value, the better is the model [65].) factor is 0.822 , while the RMSEA (Root Mean Square Error of Approximation: $<0.05$ good model fit to empirical data, 0.05-0.08 acceptable fit, 0.08-0.10 moderate fit, 0.1 unacceptable fit [66].) is 0.072. Although the CMIN/DF (Models with CMIN/DF value over 2 should be rejected, although some authors adopt less strict limits (e.g., 5 or 10) [66].) statistic differs from the norm and is over 2, it should be remembered that, for SEM models, all of the model quality measures proposed in the literature are limited to different degrees and are not objective [64].

Hypothesis 2 (H2). The influence that employee personality traits have on the degree of organizational citizenship behaviors for the environment is influenced by the demographic characteristic of employees: (H2a) sex, (H2b) age, (H2c) length of service, (H2d) type of work and (H2e) economic sector of employment.

In order to more precisely analyze the results, the model was estimated for groups distinguished by respondent sex, age, length of service, type of work and economic sector of employment. Respondents were not grouped by education, since $90 \%$ of them had a higher education. The results of the internal SEM estimated for two groups divided by sex are presented in Table 8.

Table 8. Results of internal SEM model estimation in subgroups by sex of respondent.

\begin{tabular}{|c|c|c|c|c|c|}
\hline \multirow[b]{2}{*}{ Relationship } & \multirow[b]{2}{*}{ Parameter } & \multicolumn{2}{|l|}{ Men } & \multicolumn{2}{|l|}{ Women } \\
\hline & & $\begin{array}{c}\text { Evaluation of } \\
\text { Standardized Parameters }\end{array}$ & $p$-Value & $\begin{array}{c}\text { Evaluation of } \\
\text { Standardized Parameters }\end{array}$ & $p$-Value \\
\hline Neuroticism $\rightarrow$ Direct OCBE & $\beta_{1}$ & -0.388 & 0.000 & -0.377 & 0.016 \\
\hline Extraversion $\rightarrow$ Direct OCBE & $\beta_{2}$ & -0.147 & 0.129 & -0.371 & 0.053 \\
\hline Openness to experience $\rightarrow$ Direct OCBE & $\beta_{3}$ & 0.062 & 0.443 & 0.395 & 0.086 \\
\hline Agreeableness $\rightarrow$ Direct OCBE & $\beta_{4}$ & 0.225 & 0.034 & 0.023 & 0.914 \\
\hline Conscientiousness $\rightarrow$ Direct OCBE & $\beta_{5}$ & -0.173 & 0.091 & 0.040 & 0.790 \\
\hline Neuroticism $\rightarrow$ Indirect OCBE & $\beta_{6}$ & 0.058 & 0.516 & 0.283 & 0.045 \\
\hline Extraversion $\rightarrow$ Indirect OCBE & $\beta_{7}$ & 0.368 & 0.000 & -0.026 & 0.884 \\
\hline Openness to experience $\rightarrow$ Indirect OCBE & $\beta_{8}$ & 0.118 & 0.088 & 0.640 & 0.011 \\
\hline Agreeableness $\rightarrow$ Indirect OCBE & $\beta_{9}$ & -0.225 & 0.014 & -0.337 & 0.130 \\
\hline Conscientiousness $\rightarrow$ Indirect OCBE & $\beta_{10}$ & 0.036 & 0.676 & 0.340 & 0.024 \\
\hline Direct OCBE $\rightarrow$ Indirect OCBE & $\beta_{11}$ & 0.583 & 0.000 & 0.446 & 0.000 \\
\hline Neuroticism $\leftrightarrow$ Conscientiousness & $\pi_{1}$ & -0.674 & 0.000 & -0.522 & 0.002 \\
\hline Extraversion $\leftrightarrow$ Openness to experience & $\pi_{2}$ & 0.407 & 0.000 & 0.679 & 0.000 \\
\hline Openness to experience $\leftrightarrow$ Agreeableness & $\pi_{3}$ & 0.487 & 0.000 & 0.674 & 0.001 \\
\hline Extraversion $\leftrightarrow$ Agreeableness & $\pi_{4}$ & 0.651 & 0.000 & 0.626 & 0.003 \\
\hline Agreeableness $\leftrightarrow$ Conscientiousness & $\pi_{5}$ & 0.036 & 0.442 & 0.254 & 0.022 \\
\hline \multicolumn{2}{|l|}{ Measures of model fit } & \multicolumn{2}{|l|}{$\begin{array}{c}\text { IFI }=0.809 \\
\text { RMSEA }=0.074\end{array}$} & \multicolumn{2}{|l|}{$\begin{array}{c}\text { IFI }=0.777 \\
\text { RMSEA }=0.089\end{array}$} \\
\hline
\end{tabular}

Source: Author's own research results.

The greatest discrepancies between the male and female groups were found for the influence of personality traits on indirect OCBE. Among women, indirect OCBE is significantly conditioned by Neuroticism, Openness to experience and Conscientiousness $\left(\beta_{6}, \beta_{8}, \beta_{10}\right)$. By contrast, for men, indirect behaviors are significantly more common in extraverts $\left(\beta_{7}\right)$ and less frequent in agreeable employees $\left(\beta_{9}\right)$. For direct OCBEs, among women, Extraversion significantly reduced such behaviors $\left(\beta_{2}\right)$, and in men Agreeableness significantly increased them $\left(\beta_{4}\right)$. Furthermore, in both groups, almost all relationships between personality traits were statistically significant. The only statistically insignificant relationship was between Agreeableness and Conscientiousness in men $\left(\pi_{5}\right)$. 
The results of the internal SEM estimation for the two age groups are summarized in Table 9 . The division between the groups was set at the median respondent age ( 40 years old).

Table 9. Results of internal SEM model estimation in subgroups by age of respondent.

\begin{tabular}{|c|c|c|c|c|c|}
\hline \multirow[b]{2}{*}{ Relationship } & \multirow[b]{2}{*}{ Parameter } & \multicolumn{2}{|l|}{ Up to 40} & \multicolumn{2}{|l|}{ Over 40} \\
\hline & & $\begin{array}{c}\text { Evaluation of } \\
\text { Standardized Parameters }\end{array}$ & $p$ Value & $\begin{array}{c}\text { Evaluation of } \\
\text { Standardized Parameters }\end{array}$ & $p$ Value \\
\hline Neuroticism $\rightarrow$ Direct OCBE & $\beta_{1}$ & -0.466 & 0.000 & -0.359 & 0.008 \\
\hline Extraversion $\rightarrow$ Direct OCBE & $\beta_{2}$ & -0.178 & 0.074 & -0.244 & 0.094 \\
\hline Openness to experience $\rightarrow$ Direct OCBE & $\beta_{3}$ & 0.066 & 0.506 & 0.199 & 0.115 \\
\hline Agreeableness $\rightarrow$ Direct OCBE & $\beta_{4}$ & 0.267 & 0.028 & 0.180 & 0.201 \\
\hline Conscientiousness $\rightarrow$ Direct OCBE & $\beta_{5}$ & -0.137 & 0.204 & -0.191 & 0.121 \\
\hline Neuroticism $\rightarrow$ Indirect OCBE & $\beta_{6}$ & 0.046 & 0.649 & 0.173 & 0.114 \\
\hline Extraversion $\rightarrow$ Indirect OCBE & $\beta_{7}$ & 0.390 & 0.000 & 0.208 & 0.092 \\
\hline Openness to experience $\rightarrow$ Indirect OCBE & $\beta_{8}$ & 0.190 & 0.038 & 0.085 & 0.416 \\
\hline Agreeableness $\rightarrow$ Indirect OCBE & $\beta_{9}$ & -0.278 & 0.015 & -0.119 & 0.312 \\
\hline Conscientiousness $\rightarrow$ Indirect OCBE & $\beta_{10}$ & 0.011 & 0.907 & 0.206 & 0.051 \\
\hline Direct OCBE $\rightarrow$ Indirect OCBE & $\beta_{11}$ & 0.531 & 0.000 & 0.614 & 0.000 \\
\hline Neuroticism $\leftrightarrow$ Conscientiousness & $\pi_{1}$ & -0.601 & 0.000 & -0.635 & 0.000 \\
\hline Extraversion $\leftrightarrow$ Openness to experience & $\pi_{2}$ & 0.410 & 0.000 & 0.576 & 0.000 \\
\hline Openness to experience $\leftrightarrow$ Agreeableness & $\pi_{3}$ & 0.512 & 0.000 & 0.566 & 0.000 \\
\hline Extraversion $\leftrightarrow$ Agreeableness & $\pi_{4}$ & 0.564 & 0.000 & 0.703 & 0.000 \\
\hline Agreeableness $\leftrightarrow$ Conscientiousness & $\pi_{5}$ & 0.133 & 0.042 & 0.093 & 0.124 \\
\hline Measures of model fit & & $\begin{array}{c}\mathrm{IFI}=0.820 \\
\text { RMSEA }=0.077\end{array}$ & & $\begin{array}{c}\mathrm{IFI}=0.781 \\
\mathrm{RMSEA}=0.080\end{array}$ & \\
\hline
\end{tabular}

Source: Author's own research results.

Again, the greatest discrepancies between the age groups were found for the influence of personality traits on indirect OCBE. Among the over-40s, indirect OCBE is only significantly conditioned by Conscientiousness $\left(\beta_{10}\right)$. For direct OCBEs, Agreeableness significantly increased the tendency for such behaviors in younger employees only $\left(\beta_{4}\right)$. In this case, too, almost all relationships between personality traits were statistically significant for both groups. The relationship between Agreeableness and Conscientiousness $\left(\pi_{5}\right)$ was only statistically insignificant for employees over 40 years of age.

The results of the internal SEM estimation for the two groups distinguished by length of service are summarized in Table 10. The division between the groups was set at the median length of service (10 years).

Table 10. Results of internal SEM model estimation in subgroups by length of service.

\begin{tabular}{|c|c|c|c|c|c|}
\hline \multirow[b]{2}{*}{ Relationship } & \multirow[b]{2}{*}{ Parameter } & \multicolumn{2}{|l|}{ Less than 10 Years } & \multicolumn{2}{|l|}{ Over 10 Years } \\
\hline & & $\begin{array}{c}\text { Evaluation of } \\
\text { Standardized Parameters }\end{array}$ & $p$-Value & $\begin{array}{c}\text { Evaluation of } \\
\text { Standardized Parameters }\end{array}$ & $p$-Value \\
\hline Neuroticism $\rightarrow$ Direct OCBE & $\beta_{1}$ & -0.358 & 0.002 & -0.478 & 0.006 \\
\hline Extraversion $\rightarrow$ Direct OCBE & $\beta_{2}$ & -0.186 & 0.214 & -0.180 & 0.102 \\
\hline Openness to experience $\rightarrow$ Direct OCBE & $\beta_{3}$ & 0.186 & 0.077 & 0.067 & 0.585 \\
\hline Agreeableness $\rightarrow$ Direct OCBE & $\beta_{4}$ & 0.162 & 0.320 & 0.199 & 0.103 \\
\hline Conscientiousness $\rightarrow$ Direct OCBE & $\beta_{5}$ & -0.045 & 0.623 & 0.412 & 0.154 \\
\hline Neuroticism $\rightarrow$ Indirect OCBE & $\beta_{6}$ & 0.022 & 0.793 & 0.381 & 0.016 \\
\hline Extraversion $\rightarrow$ Indirect OCBE & $\beta_{7}$ & 0.318 & 0.022 & 0.315 & 0.001 \\
\hline Openness to experience $\rightarrow$ Indirect OCBE & $\beta_{8}$ & 0.218 & 0.022 & 0.136 & 0.194 \\
\hline Agreeableness $\rightarrow$ Indirect OCBE & $\beta_{9}$ & -0.285 & 0.058 & -0.193 & 0.076 \\
\hline Conscientiousness $\rightarrow$ Indirect OCBE & $\beta_{10}$ & -0.043 & 0.594 & 0.412 & 0.006 \\
\hline Direct OCBE $\rightarrow$ Indirect OCBE & $\beta_{11}$ & 0.528 & 0.000 & 0.618 & 0.000 \\
\hline Neuroticism $\leftrightarrow$ Conscientiousness & $\pi_{1}$ & -0.467 & 0.000 & -0.762 & 0.000 \\
\hline Extraversion $\leftrightarrow$ Openness to experience & $\pi_{2}$ & 0.451 & 0.000 & 0.549 & 0.000 \\
\hline Openness to experience $\leftrightarrow$ Agreeableness & $\pi_{3}$ & 0.527 & 0.000 & 0.565 & 0.000 \\
\hline Extraversion $\leftrightarrow$ Agreeableness & $\pi_{4}$ & 0.757 & 0.000 & 0.557 & 0.000 \\
\hline Agreeableness $\leftrightarrow$ Conscientiousness & $\pi_{5}$ & 0.049 & 0.420 & 0.127 & 0.036 \\
\hline \multicolumn{2}{|l|}{ Measures of model fit } & \multicolumn{2}{|l|}{$\begin{array}{c}\text { IFI }=0.819 \\
\text { RMSEA = 0.075 }\end{array}$} & \multicolumn{2}{|l|}{$\begin{array}{c}\text { IFI }=0.784 \\
\text { RMSEA }=0.080\end{array}$} \\
\hline
\end{tabular}


The only discrepancies between the length-of-service groups were found in the influence of personality traits on indirect OCBE. Among employees with under 10 years' experience, only Extraversion and Openness to experience statistically significantly shaped such behavior $\left(\beta_{7}, \beta_{8}\right)$. For employees of greater experience, Neuroticism, Extraversion and Conscientiousness $\left(\beta_{6}, \beta_{7}, \beta_{10}\right)$ had a statistically significant impact on indirect OCBE. Almost all relationships between personality traits were statistically significant in both analyzed groups. The only statistically insignificant relationship was between Agreeableness and Conscientiousness for employees of greater than 10 years' experience $\left(\pi_{5}\right)$.

The results of the internal SEM estimation for two groups distinguished by type of work (i.e., office/clerical and management) are summarized in Table 11. The group of blue-collar employees was omitted due to its small size ( $0.4 \%$ of respondents).

Table 11. Results of internal SEM model estimation in subgroups by type of work.

\begin{tabular}{|c|c|c|c|c|c|}
\hline \multirow[b]{2}{*}{ Relationship } & \multirow[b]{2}{*}{ Parameter } & \multicolumn{2}{|l|}{ Office/Clerical } & \multicolumn{2}{|l|}{ Management } \\
\hline & & $\begin{array}{c}\text { Evaluation of } \\
\text { Standardized Parameters }\end{array}$ & $p$-Value & $\begin{array}{c}\text { Evaluation of } \\
\text { Standardized Parameters }\end{array}$ & $p$-Value \\
\hline Neuroticism $\rightarrow$ Direct OCBE & $\beta_{1}$ & -0.390 & 0.000 & -0.513 & 0.022 \\
\hline Extraversion $\rightarrow$ Direct OCBE & $\beta_{2}$ & -0.160 & 0.113 & -0.324 & 0.106 \\
\hline Openness to experience $\rightarrow$ Direct OCBE & $\beta_{3}$ & 0.101 & 0.254 & 0.074 & 0.595 \\
\hline Agreeableness $\rightarrow$ Direct OCBE & $\beta_{4}$ & 0.177 & 0.121 & 0.283 & 0.212 \\
\hline Conscientiousness $\rightarrow$ Direct OCBE & $\beta_{5}$ & -0.106 & 0.225 & -0.216 & 0.297 \\
\hline Neuroticism $\rightarrow$ Indirect OCBE & $\beta_{6}$ & 0.089 & 0.255 & 0.337 & 0.102 \\
\hline Extraversion $\rightarrow$ Indirect OCBE & $\beta_{7}$ & 0.355 & 0.000 & 0.283 & 0.125 \\
\hline Openness to experience $\rightarrow$ Indirect OCBE & $\beta_{8}$ & 0.211 & 0.007 & 0.036 & 0.767 \\
\hline Agreeableness $\rightarrow$ Indirect OCBE & $\beta_{9}$ & -0.295 & 0.005 & -0.079 & 0.695 \\
\hline Conscientiousness $\rightarrow$ Indirect OCBE & $\beta_{10}$ & 0.050 & 0.502 & 0.344 & 0.073 \\
\hline Direct OCBE $\rightarrow$ Indirect OCBE & $\beta_{11}$ & 0.581 & 0.000 & 0.592 & 0.000 \\
\hline Neuroticism $\leftrightarrow$ Conscientiousness & $\pi_{1}$ & -0.161 & 0.000 & -0.704 & 0.000 \\
\hline Extraversion $\leftrightarrow$ Openness to experience & $\pi_{2}$ & 0.173 & 0.000 & 0.386 & 0.024 \\
\hline Openness to experience $\leftrightarrow$ Agreeableness & $\pi_{3}$ & 0.155 & 0.000 & 0.505 & 0.013 \\
\hline Extraversion $\leftrightarrow$ Agreeableness & $\pi_{4}$ & 0.184 & 0.000 & 0.712 & 0.000 \\
\hline Agreeableness $\leftrightarrow$ Conscientiousness & $\pi_{5}$ & 0.018 & 0.233 & 0.162 & 0.048 \\
\hline \multicolumn{2}{|l|}{ Measures of model fit } & \multicolumn{2}{|l|}{$\begin{array}{c}\text { IFI }=0.822 \\
\text { RMSEA }=0.073\end{array}$} & \multicolumn{2}{|l|}{$\begin{array}{c}\text { IFI }=0.739 \\
\text { RMSEA }=0.090\end{array}$} \\
\hline
\end{tabular}

Source: Author's own research results.

In the work-type groups, the only discrepancies are in the influence of personality traits on indirect OCBE. Here, the managerial group exhibits no statistically significant relationships, while among the clerical and office employees only Neuroticism and Conscientiousness had an influence. In terms of relationship between employee personality types, for office/clerical employees, the relationship between Agreeableness and Conscientiousness $\left(\pi_{5}\right)$ was statistically insignificant. All other relationships were statistically significant.

Finally, the influence of employment sector (private vs. public) on the studied dependence was modeled. The results of the internal SEM estimation for these two groups are summarized in Table 12. 
Table 12. Results of internal SEM model estimation in subgroups by sector of employment.

\begin{tabular}{|c|c|c|c|c|c|}
\hline \multirow[b]{2}{*}{ Relationship } & \multirow[b]{2}{*}{ Parameter } & \multicolumn{2}{|l|}{ Private } & \multicolumn{2}{|l|}{ Public } \\
\hline & & $\begin{array}{c}\text { Evaluation of } \\
\text { Standardized Parameters }\end{array}$ & $p$-Value & $\begin{array}{c}\text { Evaluation of } \\
\text { Standardized Parameters }\end{array}$ & $p$-Value \\
\hline Neuroticism $\rightarrow$ Direct OCBE & $\beta_{1}$ & -0.461 & 0.000 & -0.322 & 0.009 \\
\hline Extraversion $\rightarrow$ Direct OCBE & $\beta_{2}$ & -0.138 & 0.276 & -0.226 & 0.052 \\
\hline Openness to experience $\rightarrow$ Direct OCBE & $\beta_{3}$ & 0.104 & 0.307 & 0.079 & 0.458 \\
\hline Agreeableness $\rightarrow$ Direct OCBE & $\beta_{4}$ & 0.269 & 0.062 & 0.162 & 0.191 \\
\hline Conscientiousness $\rightarrow$ Direct OCBE & $\beta_{5}$ & -0.275 & 0.026 & 0.022 & 0.838 \\
\hline Neuroticism $\rightarrow$ Indirect OCBE & $\beta_{6}$ & 0.341 & 0.004 & -0.035 & 0.720 \\
\hline Extraversion $\rightarrow$ Indirect OCBE & $\beta_{7}$ & 0.343 & 0.002 & 0.286 & 0.005 \\
\hline Openness to experience $\rightarrow$ Indirect OCBE & $\beta_{8}$ & 0.128 & 0.135 & 0.186 & 0.046 \\
\hline Agreeableness $\rightarrow$ Indirect OCBE & $\beta_{9}$ & -0.178 & 0.148 & -0.222 & 0.043 \\
\hline Conscientiousness $\rightarrow$ Indirect OCBE & $\beta_{10}$ & 0.088 & 0.396 & 0.119 & 0.200 \\
\hline Direct OCBE $\rightarrow$ Indirect OCBE & $\beta_{11}$ & 0.624 & 0.000 & 0.513 & 0.000 \\
\hline Neuroticism $\leftrightarrow$ Conscientiousness & $\pi_{1}$ & -0.589 & 0.000 & -0.653 & 0.000 \\
\hline Extraversion $\leftrightarrow$ Openness to experience & $\pi_{2}$ & 0.413 & 0.000 & 0.506 & 0.000 \\
\hline Openness to experience $\leftrightarrow$ Agreeableness & $\pi_{3}$ & 0.462 & 0.000 & 0.581 & 0.000 \\
\hline Extraversion $\leftrightarrow$ Agreeableness & $\pi_{4}$ & 0.650 & 0.000 & 0.669 & 0.000 \\
\hline Agreeableness $\leftrightarrow$ Conscientiousness & $\pi_{5}$ & 0.156 & 0.032 & 0.006 & 0.904 \\
\hline Measures of model fit & & $\begin{array}{c}\text { IFI }=0.785 \\
\text { RMSEA }=0.083\end{array}$ & & $\begin{array}{c}\text { IFI }=0.801 \\
\text { RMSEA }=0.077\end{array}$ & \\
\hline
\end{tabular}

Source: Author's own research results.

In this case, too, the greatest discrepancies between groups were found for the influence of personality traits on indirect OCBE. Among private sector employees, Neuroticism and Extraversion significantly shape these behaviors $\left(\beta_{6}, \beta_{7}\right)$. Meanwhile, in the public sector, indirect OCBE is instead significantly more common for trait Openness to experience $\left(\beta_{8}\right)$ and less common for Agreeableness $\left(\beta_{6}, \beta_{7}\right)$. For direct OCBEs, Neuroticism significantly reduced behaviors in both sectors $\left(\beta_{1}\right)$, while Conscientiousness reduced them only in the private sector $\left(\beta_{6}, \beta_{7}\right)$. Almost all relationships between personality traits are statistically significant-only the relationship between Agreeableness and Conscientiousness $\left(\beta_{6}, \beta_{7}\right)$ in the public sector was statistically insignificant.

It should be noted that most of the analyzed models of subgroups distinguished by sex and age of respondent, as well as length of service, type of work and economic sector of employment, are assessed to have a correct and satisfactory fit with the empirical data. In half of the cases, the IFI was over 0.8 (for the subgroups: men, age up to 40 years, experience of up to 10 years, office/clerical work, public sector), while the RMSEA was in most cases in the range 0.05-0.08; the upper value of this range was exceeded for three subgroups: women, management positions, private sector.

\section{Discussion and Conclusions}

The main insight based on the research is that OCBEs (including energy-saving practices) are significant influenced by the personality of employees. The strongest predictors of direct OCBEs turned out to be Neuroticism (negative effect) and Agreeableness (positive effect). In the case of such behaviors, the energy-saving items that were most significantly affected by employees' personality were: I am a person who turns off my lights when leaving my office for any reason; I am a person who turns off the lights in a vacant room; I am a person who makes sure all of the lights are turned off if I am the last to leave [11,16]. These items dominated the construct of direct OCBEs, which is evidence for relevance of energy saving and sustainable energy consumption in research on green behaviors at work [15].

Meanwhile, with regard to indirect OCBEs, the strongest predictors were Extraversion (positive impact) and Agreeableness (negative impact). There seems to be a logical justification for this (see $[27,39])$. Neurotic people are more pessimistic and stressed and are less inclined to engage in $\mathrm{OCB}$, but more inclined towards CWB (mainly in the form of passive behaviors, including withdrawal). Engagement in direct OCBE requires being active and showing initiative. In turn, agreeable employees are empathic, and so are 
more willing to engage in various initiatives, including those of utilitarian importance, such as environmental protection. With regard to indirect OCBEs, it is no surprise that extravert employees most often engage in such behavior. They are open, sociable and relationship-oriented, and this is required for willingness to engage others in various types of pro-environmental activities. By contrast, agreeable people are less inclined to impose their opinions or views on others and will be more opportunistic in dealing with other employees, and thus reluctant to engage in indirect OCBEs.

It is somewhat surprising, however, that Conscientiousness has no statistically significant influence on direct or indirect OCBEs. Because OCBEs are voluntary behaviors, from the theory point of view, the main personality traits within the FFM that influence such behaviors should be such traits as Conscientiousness and Emotional Stability (or Neuroticism) [62]. The insignificant influence of Conscientiousness is astonishing, since conscientious people are dutiful, rules-compliant and achievement-oriented. Furthermore, the fact that such employees go beyond role requirement (OCB) and avoid CWB [40] also suggests that they should tend towards OCBEs.

The second main insight of the research is that the analyzed demographic variables (i.e., sex and age, as well as length of service, type of work and economic sector of employment) statistically significantly moderated the relationship between personality traits and, mainly, indirect OCBE, including energy saving at work. This mainly applied to women, employees of up to 40 years of age and over 10 years' experience, office/clerical employees, and public sector employees.

The mentioned insights provide a better understanding of the mechanisms of OCBEs, such as energy saving at work. It contributes not only to the theory of management, but also to companies' operational practice.

Organizations and supervisors that want to reduce resource consumption (including energy) should support employees and appreciate their activities [2], taking into consideration the personality and demographic characteristics of their staff. It is crucial to understand the importance of employees' daily practices for greening the company and energy saving. Personalizing this support will help maximize the efficiency of sustainable behaviors for the company and the environment.

Individuals tend more towards OCBEs if they feel supported $[3,19,23]$. OCBEs are a way in which employees repay the organization's recognition and support for their efforts to reduce the organization's consumption of resources and to create a more sustainable environment [2]. Organizational support involves the organization conducting the right policy to inform about environmental issues, encouraging employees and recognizing them for participating in environmental initiatives [23]. In other words, supervisors must develop between employees an awareness of the significance of environmental issues, and they must equip employees with sufficient resources to engage in OCBE $[4,19]$. There are many ways in which an organization can show that it focuses on environmental issues, such as making recycling containers available.

It is worth mentioning that this organizational support should not be only discretionary but legally regulated. This would help sustainable practices to be implemented in companies that are hesitant in this field.

The article has some important limitations that should be discussed. The data was collected by self-reports and so the common variance method may cause a bias. There are many controversies about such measurement. For example, Organ and Ryan [67] argued that measurement of OCBs should use reporting by others (e.g., coworkers), which should help to limit bias in the data. On the other hand, supervisors have only limited knowledge of OCBs [68]. The use of reporting by others is justified primarily if there is a need to research employee-coworker relationships [21]. Future studies in this area should use less subjective measuring instruments.

The data is not representative of the population, because the employees in the study were selected not randomly, but intentionally. In future research it is important to ensure a representative sample. 
Furthermore, the data was collected in a single time period, so it was impossible to test the influence of time. Future research should be based on longitudinal data investigating changes in OCBEs resulting from personality traits.

The instrument used in this study contains only selected forms of OCBE. There are many other potential examples of OCBE that could be taken into account. Therefore, future studies should research other behaviors overlooked in this article (e.g., sportsmanship).

The study did not consider specific unobservable variables, such as: organizational culture; organizational strategies; company practices, policies or norms in the field of sustainability; managerial attributes; and talents or incentives. These variables can impact personality traits, OCBEs and the relationship between these two factors [69].

Additionally, in future research it is crucial to find the relationships between OCBE and OCBs in general $[20,21]$. Future research should take into account the relationship between pro-environmental voluntary behaviors outside the workplace (in private life) and OCBEs (of which the former has been far more thoroughly studied than the latter; [1]). Boiral [20] pointed out that ecological activity within an organization is also motivated by the environmental sensitivity of employees in their private life. Citizens are often concerned about environmental issues, and they often transfer their environmental concerns to their professional activity. Many ecological behaviors are very similar in these two spheres (e.g., saving energy, recycling, eco-friendly transport) (e.g., see [1]). Of course, there are also significant differences between work and non-work sustainable behaviors, mainly because the costs outside are borne directly by the individual [1]. In any event, confirmation of the relationship between private-life and occupational OCBE will confirm the importance of environmental education and information, and of promoting pro-environmental values and sensitivity. Recent studies suggest that pro-environmental attitudes and overall education have much more influence on OCBE than formal ecological knowledge or programs [70].

Funding: The project was funded by the National Science Centre, Poland, on the Decision No. 2020/37/B/HS4/00988.

Institutional Review Board Statement: Not applicable.

Informed Consent Statement: Informed consent was obtained from all subjects involved in the study.

Data Availability Statement: Publicly available datasets were analyzed in this study. This data can be found at the following link: https:/ / docs.google.com/spreadsheets/d/12c_nKo0JDaUUcUm4 gDHQIOsqvPP1MMiv3ikPVx1Fghk/edit?usp=sharing (accessed on 10 May 2021).

Conflicts of Interest: The author declares no conflict of interest.

\section{Appendix A. Organizational Citizenship Behavior toward the Environment Scale Items}

The series of questions below asks you to reflect on some of your typical behaviors at work. Please consider the place where you currently work. All items were rated on a 7 -point scale, 1 = strongly disagree, 2 = disagree, $3=$ somewhat disagree, $4=$ neither agree nor disagree, $5=$ somewhat agree, $6=$ agree and $7=$ strongly agree.

OCBE direct

1. I am a person who recycles my bottles, cans, and other containers.

2. I am a person who uses scrap paper for notes instead of fresh paper.

3. I am a person who prints double-sided.

4. I am a person who turns off my lights when leaving my office for any reason.

5. I am a person who recycles used paper.

6. I am a person who powers off my computer when away for more than $3 \mathrm{~h}$.

7. I am a person who turns off the lights in a vacant room.

8. I am a person who makes sure all of the lights are turned off if I am the last to leave.

9. I am a person who powers down all desk electronics at the end of the day.

10. I am a person who uses a reusable water bottle instead of a paper cup at the water cooler or faucet.

11. I am a person who uses a reusable coffee cup instead of a paper cup. 
12. I am a person who properly disposes of electronic waste. OCBE indirect

1. I spontaneously give my time to help my colleagues take the environment into account in everything they do at work.

2. I encourage my colleagues to adopt more environmentally conscious behaviors.

3. I encourage my colleagues to express their ideas and opinions on environmental issues.

4. In my work, I weigh the consequences of my actions before doing something that could affect the environment.

5. I voluntarily carry out environmental actions and initiatives in my daily work activities.

6. I make suggestions to my colleagues about ways to protect the environment more effectively, even when it is not my direct responsibility.

7. I actively participate in environmental events organized in and/or by my company.

8. I stay informed about my company's environmental initiatives.

9. I undertake environmental actions that contribute positively to the image of my organization.

10. I volunteer for projects, endeavors, or events that address environmental issues in my organization.

Source: Direct OCBE [2]; Indirect OCBE [20].

\section{Appendix B. International Personality Item Pool NEO-Five Factor Inventory-50}

Read carefully the following sentences that describe people's different behaviors, feelings and thoughts.
Think about each of them-to what extent does it also describe you as you usually are? People are very different, so there are no right or wrong answers here. Simply answer honestly each time to what extent the statement describes you.

(1-describes me completely incorrectly, 2-describes me rather incorrectly,

3-a bit accurate and a bit inaccurate describes me, 4-describes me rather accurately, 5-describes me completely)

\begin{tabular}{|l|l|l|l|l|l|}
\hline 1. $\quad$ I often have mood swings & 1 & 2 & 3 & 4 & 5 \\
\hline 2. $\quad$ I stay aside & 1 & 2 & 3 & 4 & 5 \\
\hline 3. $\quad$ I have a vivid imagination & 1 & 2 & 3 & 4 & 5 \\
\hline 4. $\quad$ I can hurt others & 1 & 2 & 3 & 4 & 5 \\
\hline 5. $\quad$ I make plans and stick to them closely & 1 & 2 & 3 & 4 & 5 \\
\hline 6. $\quad$ It is difficult to alarm me with something & 1 & 2 & 3 & 4 & 5 \\
\hline 7. $\quad$ I feel great among people & 1 & 2 & 3 & 4 & 5 \\
\hline 8. $\quad$ I avoid philosophical discussions & 1 & 2 & 3 & 4 & 5 \\
\hline 9. $\quad$ In my company, others feel at ease & 1 & 2 & 3 & 4 & 5 \\
\hline 10. $\quad$ I only do as much as I need to & 1 & 2 & 3 & 4 & 5 \\
\hline 11. $\quad$ I am often depressed & 1 & 2 & 3 & 4 & 5 \\
\hline 12. $\quad$ I have little to say & 1 & 2 & 3 & 4 & 5 \\
\hline 13. $\quad$ I am inclined to vote for liberal politicians & 1 & 2 & 3 & 4 & 5 \\
\hline 14. $\quad$ I play on others & 1 & 2 & 3 & 4 & 5 \\
\hline 15. $\quad$ I systematically implement what I have planned & 1 & 2 & 3 & 4 & 5 \\
\hline 16. $\quad$ I am pleased with myself & 1 & 2 & 3 & 4 & 5 \\
\hline 17. $\quad$ I make friends easily & 1 & 2 & 3 & 4 & 5 \\
\hline 18. I don't like art & 1 & 2 & 3 & 4 & 5 \\
\hline
\end{tabular}




\begin{tabular}{|c|c|c|c|c|c|c|}
\hline 19. & I believe others have good intentions & 1 & 2 & 3 & 4 & 5 \\
\hline 20. & I don't bring things to the end & 1 & 2 & 3 & 4 & 5 \\
\hline 21. & I often get depressed & 1 & 2 & 3 & 4 & 5 \\
\hline 22. & I don't say much & 1 & 2 & 3 & 4 & 5 \\
\hline 23. & I believe that art is important & 1 & 2 & 3 & 4 & 5 \\
\hline 24. & I suspect others of hidden intentions & 1 & 2 & 3 & 4 & 5 \\
\hline 25. & I pay attention to details & 1 & 2 & 3 & 4 & 5 \\
\hline 26. & I rarely feel depressed & 1 & 2 & 3 & 4 & 5 \\
\hline 27. & I am the life of the party & 1 & 2 & 3 & 4 & 5 \\
\hline 28. & I don't like going to art galleries & 1 & 2 & 3 & 4 & 5 \\
\hline 29. & I accept people as they are & 1 & 2 & 3 & 4 & 5 \\
\hline 30. & It's hard for me to get down to business & 1 & 2 & 3 & 4 & 5 \\
\hline 31. & I don't like myself & 1 & 2 & 3 & 4 & 5 \\
\hline 32. & I would describe my experiences as rather monotonous & 1 & 2 & 3 & 4 & 5 \\
\hline 33. & I like getting to know new ideas & 1 & 2 & 3 & 4 & 5 \\
\hline 34. & I have a sharp tongue & 1 & 2 & 3 & 4 & 5 \\
\hline 35. & I fulfil my daily duties without delay & 1 & 2 & 3 & 4 & 5 \\
\hline 36. & I feel good with myself & 1 & 2 & 3 & 4 & 5 \\
\hline 37. & I can deal with social situations & 1 & 2 & 3 & 4 & 5 \\
\hline 38. & I am inclined to vote for conservative politicians & 1 & 2 & 3 & 4 & 5 \\
\hline 39. & I respect other people & 1 & 2 & 3 & 4 & 5 \\
\hline 40. & I forget about my responsibilities & 1 & 2 & 3 & 4 & 5 \\
\hline 41. & I panic easily & 1 & 2 & 3 & 4 & 5 \\
\hline 42. & I don't like getting attention & 1 & 2 & 3 & 4 & 5 \\
\hline 43. & I take care of a high level of discussion & 1 & 2 & 3 & 4 & 5 \\
\hline 44. & I often offend others & 1 & 2 & 3 & 4 & 5 \\
\hline 45. & I am always prepared & 1 & 2 & 3 & 4 & 5 \\
\hline & I rarely get irritated & 1 & 2 & 3 & 4 & 5 \\
\hline & I know how to get people interested & 1 & 2 & 3 & 4 & 5 \\
\hline & I am not interested in abstract ideas & 1 & 2 & 3 & 4 & 5 \\
\hline & I have a good word for everyone & 1 & 2 & 3 & 4 & 5 \\
\hline & I'm wasting my time & 1 & 2 & 3 & 4 & 5 \\
\hline
\end{tabular}

Factors of personality traits and their related checklist item numbers: Neuroticism: 1 6, 11, 16, 21, 26, 31, 36, 41, 46; Extraversion: 2, 7, 12, 17, 22, 27, 32, 37, 42, 47; Agreeableness: 4, 9, 14, 19, 24, 29, 34, 39, 44, 49; Openness to experience: 3, 8, 13, 18, 23, 28, 33, 38, 43, 48; Conscientiousness: $5,10,15,20,25,30,35,40,45,50$. Source: author's own work based on [58].

\section{References}

1. Lo, S.H.; Peters, G.-J.Y.; Kok, G. A Review of Determinants of and Interventions for Proenvironmental Behaviors in Organizations. J. Appl. Soc. Psychol. 2012, 42, 2933-2967. [CrossRef]

2. Lamm, E.; Tosti-Kharas, J.; Williams, E.G. Read This Article, but Don't Print It: Organizational Citizenship Behavior toward the Environment. Group Organ. Manag. 2013, 38, 163-197. [CrossRef]

3. Norton, T.A.; Parke, S.L.; Zacher, H.; Ashkanasy, N.M. Employee Green Behavior: A Theoretical Framework, Multilevel Review, and Future Research Agenda. Organ. Environ. 2015, 28, 103-125. [CrossRef] 
4. Raineri, N.; Paillé, P. Linking corporate policy and supervisory support with environmental citizenship behaviors: The role of employee environmental beliefs and commitment. J. Bus. Ethics 2016, 137, 129-148. [CrossRef]

5. Dumont, J.; Shen, J.; Deng, X. Effects of Green HRM Practices on Employee Workplace Green Behavior: The Role of Psychological Green Climate and Employee Green Values. Hum. Resour. Manag. 2017, 56, 613-627. [CrossRef]

6. Dilchert, S. Counterproductive sustainability behaviors and their relationship to personality traits. Int. J. Sel. Assess. 2018, 26, 49-56. [CrossRef]

7. Ramus, C.A.; Killmer, A.B. Corporate greening through prosocial extrarole behaviors-A conceptual framework for employee motivation. Bus. Strategy Environ. 2007, 16, 554-570. [CrossRef]

8. Ones, D.; Dilchert, S. Environmental Sustainability at Work: A Call to Action. Ind. Organ. Psychol. 2012, 5, 447-469. [CrossRef]

9. Kim, Y.J.; Kim, W.G.; Choi, H.-M.; Phetvaroon, K. The effect of green human resource management on hotel employees'ecofriendly behavior and environmental performance. Int. Hosp. Manag. 2019, 76, 83-93. [CrossRef]

10. Waddock, S.; McIntosh, M. Beyond corporate responsibility: Implications for management development. Bus. Soc. Rev. 2009, 114, 295-325. [CrossRef]

11. Littleford, C.; Ryley, T.J.; Firth, S.K. Context, control and the spillover of energy use behaviors between office and home settings. J. Environ. Psychol. 2014, 40,157-166. [CrossRef]

12. The UN Sustainable Development Goals. Available online: https://www.un.org/sustainabledevelopment (accessed on 10 May 2021).

13. Abrahamse, W.; Steg, L.; Vlek, C.; Rothengatter, T. A review of intervention studies aimed at household energy conservation. J. Environ. Psychol. 2005, 25, 273-291. [CrossRef]

14. Owens, S.; Driffill, L. How to change attitudes and behaviors in the context of Energy. Energy Policy 2008, 36, 4412-4418. [CrossRef]

15. Brown, N.; Wright, A.J.S.; Shukla, A.; Stuart, G. Longitudinal analysis of energy metering data from non-domestic buildings. Build. Res. Inf. 2010, 38, 80-91. [CrossRef]

16. Siero, F.W.; Bakker, A.B.; Dekker, G.B.; Van Den Burg, M.T.C. Changing organizational energy consumption behavior through comparative feedback. J. Environ. Psychol. 1996, 16, 235-246. [CrossRef]

17. Kollmuss, A.; Agyeman, J. Mind the gap: Why do people act environmentally and what are the barriers to pro-environmental behavior? Environ. Educ. Res. 2002, 8, 239-260. [CrossRef]

18. Kramar, R. Beyond strategic human resource management: Is sustainable human resource management the next approach? Int. J. Hum. Resour. Manag. 2014, 25, 1069-1089. [CrossRef]

19. Paillé, P.; Boiral, O.; Chen, Y. Linking environmental management practices and organizational citizenship behavior for the environment: A social exchange perspective. Int. J. Hum. Resour. Manag. 2013, 24, 3552-3575. [CrossRef]

20. Boiral, O. Greening the corporation through organizational citizenship behaviors. J. Bus. Ethics 2009, 87, 221-236. [CrossRef]

21. Boiral, O.; Paillé, P. Organizational citizenship behavior for the environment: Measurement and validation. J. Bus. Ethics 2012, 109, 431-445. [CrossRef]

22. Daily, B.F.; Bishop, J.W.; Govindarajulu, N. A Conceptual Model for Organizational Citizenship Behavior Directed Toward the Environment. Bus. Soc. 2009, 48, 243-256. [CrossRef]

23. Alt, E.; Spitzeck, H. Improving environmental performance through unit-level organizational citizenship behaviors for the environment: A capability perspective. J. Environ. Manag. 2016, 1, 48-58. [CrossRef]

24. Egri, C.P.; Herman, S. Leadership in the North American environmental sector: Values, leadership styles, and contexts of environmental leaders and their organizations. Acad. Manag. J. 2000, 43, 571-604. [CrossRef]

25. Homburg, A.; Stolberg, A. Explaining pro-environmental behavior with a cognitive theory of stress. J. Environ. Psychol. 2006, 26, 1-14. [CrossRef]

26. Gkorezis, P. Supervisor support and pro-environmental behavior: The mediating role of LMX. Manag. Decis. 2015, 53, 1045-1060. [CrossRef]

27. Mount, M.; Ilies, R.; Johnson, E. Relationship of personality traits and counterproductive work behaviors: The mediating effects of job satisfaction. Pers. Psychol. 2006, 59, 591-622. [CrossRef]

28. Ferreira, M.F.; Nascimento, E. Relationship between personality traits and counterproductive work behaviors. Psico USF Bragança Paul. 2016, 21, 677-685. [CrossRef]

29. Miller, J.D.; Lynam, D.; Leukefeld, C. Examining antisocial behavior through the lens of the Five Factor Model of personality. Aggress. Behav. 2003, 29, 497-514. [CrossRef]

30. Furnham, A.; Miller, T. Personality, absenteeism and productivity. Personal. Individ. Differ. 1997, 23, 705-707. [CrossRef]

31. Collins, J.M.; Schmidt, F.L. Personality, integrity, and white collar crime: A construct validity study. Pers. Psychol. 1993, 46, 295-311. [CrossRef]

32. Arthur, W., Jr.; Graziano, W.G. The five-factor model, conscientiousness, and driving accident involvement. J. Personal. 1996, 64, 593-618. [CrossRef]

33. Szostek, D.; Balcerzak, A.P.; Rogalska, E. The relationship between personality, organizational and interpersonal counterproductive work behaviors. Moderating role of demographic and professional features of employees in Poland. Acta Montan. Slovaca 2020, 25. [CrossRef]

34. Costa, P.T.; McCrae, R.R. Revised NEO Personality Inventory (NEO-PI-R) and NEO Five-Factor Inventory (NEO-FFI) Professional Manual; Psychological Assessment Resources: Odessa, FL, USA, 1992. 
35. Costa, P.T.; McCrae, R.R.; Dye, D.A. Facet scales for agreeableness and conscientiousness: A revision of the NEO Personality Inventory. Personal. Individ. Differ. 1991, 12, 887-898. [CrossRef]

36. Goldberg, L.R. The structure of phenotypic personality traits. Am. Psychol. 1993, 48, 26-34. [CrossRef] [PubMed]

37. Costa, P.T.; McCrae, R.R. Personality in adulthood: A six-year longitudinal of self-reports and spouse ratings on the NEO Personality Inventory. J. Personal. Soc. Psychol. 1988, 54, 853-863. [CrossRef]

38. Costa, P.T.; McCrae, R.R. Personality disorders and the five-factor model of personality. J. Personal. Disord. 1990, 4, 362-371. [CrossRef]

39. Skarlicki, D.P.; Folger, R.; Tesluk, P. Personality as a moderator in the relationship between fairness and retaliation. Acad. Manag. J. 1999, 42, 100-108. [CrossRef]

40. Ones, D.S.; Viswesvaran, C. Integrity tests and other criterion-focused occupational personality scales (COPS) used in personnel selection. Int. J. Sel. Assess. 2001, 9, 31-39. [CrossRef]

41. Block, J. A contrarian view of the five-factor approach to personality description. Psychol. Bull. 1995, 117, 187-215. [CrossRef] [PubMed]

42. Judge, T.A.; Martocchio, J.J.; Thoresen, C.J. Five-factor model of personality and employee absence. J. Appl. Psychol. 1997, 82, 745-755. [CrossRef]

43. Jensen-Campbell, L.A.; Graziano, W.G. Agreeableness as a Moderator of Interpersonal Conflict. J. Personal. 2001, 69, 323-361. [CrossRef]

44. Briggs, S.R. The optimal level of measurement for personality constructs. In Personality Psychology: Recent Trends and Emerging Directions; Buss, D.M., Cantor, N., Eds.; Springer: New York, NY, USA, 1989; pp. 246-260.

45. Marcus, B.; Lee, K.; Ashton, M.C. Personality dimensions explaining relationships between integrity tests and counterproductive behavior: Big five, or one in addition? Pers. Psychol. 2007, 60, 1-34. [CrossRef]

46. Lee, K.; Ashton, M.C.; Shin, K.-H. Personality Correlates of Workplace Anti-Social Behavior. Appl. Psychol. Int. Rev. 2005, 54, 81-98. [CrossRef]

47. Organ, D.W. Organizational Citizenship Behavior-The Good Soldier Syndrome; D.C. Health: Lexington, MA, USA, 1988.

48. Brief, A.P.; Motowidlo, S.J. Prosocial organizational behaviors. Acad. Manag. Rev. 1986, 11, 710-725. [CrossRef]

49. George, J.M.; Brief, A.P. Feeling Good-Doing Good: A Conceptual Analysis of the Mood at Work-Organizational Spontaneity Relationship. Psychol. Bull. 1992, 112, 310-329. [CrossRef] [PubMed]

50. Borman, W.C.; Motowidlo, S.J. Expanding the Criterion Domain to Include Elements of Contextual Performance. In Personal Selection in Organizations; Schmitt, W.C., Borman, W.C., Eds.; Jossey-Bass: New York, NY, USA, 1993; pp. 71-98.

51. Organ, D.W. Organizational Citizenship Behavior: It's construct Clean-Up Time. Hum. Perform. 1997, 10, 85-97. [CrossRef]

52. Glińska-Neweś, A.; Szostek, D. Organizational citizenship behaviors in public and private sector. Int. J. Contemp. Manag. 2018, 17, 45-58. [CrossRef]

53. Organ, D.W.; Podsakoff, P.M.; MacKenzie, S.B. Organizational Citizenship Behavior: Its Nature, Antecedents, and Consequences; Sage Publications: Thousand Oaks, CA, USA, 2006.

54. Podsakoff, P.M.; MacKenzie, S.B.; Paine, J.B.; Bachrach, D.G. Organizational Citizenship Behaviors: A Critical Review of the Theoretical and Empirical Literature and Suggestions for Future Research. J. Manag. 2000, 26, 513-563. [CrossRef]

55. Spector, P.E.; Fox, S. Counterproductive Work Behavior and Organizational Citizenship Behavior: Are They Opposite Forms of Active Behavior? Appl. Psychol. Int. Rev. 2010, 59, 21-39. [CrossRef]

56. Ciocirlan, C.E. Environmental workplace behaviors: Definition matters. Organ. Environ. 2017, 30, 51-70. [CrossRef]

57. Ones, D.S.; Viswesvaran, C.; Schmidt, F.L. Personality and absenteeism: A meta-analysis of integrity tests. Eur. J. Personal. 2003, 17, 19-38. [CrossRef]

58. Goldberg, L.R. The development of markers of the Big Five factor structure. Psychol. Assess. 1992, 4, 26-42. [CrossRef]

59. Strus, W.; Cieciuch, J.; Rowiński, T. The Polish adaptation of the IPIP-BFM-50 questionnaire for measuring five personality traits in the lexical approach. Rocz. Psychol. Ann. Psychol. 2014, 17, 347-366.

60. Mount, M.K.; Barrick, M.R.; Strauss, J.P. Validity of observer ratings of the Big Five personality dimensions. J. Appl. Psychol. 1994, 79, 272-280. [CrossRef]

61. Saucier, G.; Ostendorf, F. Hierarchical components of the Big Five personality factors: A cross-language replication. J. Personal. Soc. Psychol. 1999, 76, 613-627. [CrossRef]

62. Barrick, M.R.; Mount, M.K.; Judge, T.A. Personality and performance at the beginning of the new millennium: What do we know and where do we go next? Personal. Perform. 2001, 9, 9-30. [CrossRef]

63. Saucier, G.; Goldberg, L.R. The structure of personality attributes. In Personality and Work: Reconsidering the Role of Personality in Organizations; Barrick, M.R., Ryan, A.M., Eds.; Jossey-Bass: San Francisco, CA, USA, 2003; pp. 1-29.

64. Salgado, J.F. The Big Five personality dimensions and counterproductive behaviors. Int. J. Sel. Assess. 2002, 10, 117-125. [CrossRef]

65. Żurek, M. Inklinacje Behawioralne na Rynkach Kapitałowych w Świetle Modeli SEM; Wydawnictwo Naukowe Uniwersytetu Mikołaja Kopernika: Toruń, Poland, 2016.

66. Bedyńska, S.; Książek, M. Statystyczny Drogowskaz 3. Praktyczny Przewodnik Wykorzystania Modeli Regresji Oraz Równań Strukturalnych; Wydawnictwo Akademickie Sedno: Warszawa, Poland, 2012. 
67. Organ, D.W.; Ryan, K. A meta-analytic review of attitudinal and dispositional predictors of organizational citizenship behavior. Pers. Psychol. 1995, 48, 775-802. [CrossRef]

68. Vandenberg, R.; Lance, C.; Taylor, S. A latent variable approach to rating source of equivalence: Who should provide ratings on organizational citizenship behavior dimensions. In Handbook of Organizational Citizenship Behavior: A Review of 'Good Solder' Activity in Organizations; Turnipseed, D.L., Ed.; Nova Science Publishers: New York, NY, USA, 2005; pp. $109-141$.

69. Coles, J.L.; Li, Z.F. An Empirical Assessment of Empirical Corporate Finance. Soc. Sci. Res. Netw. J. 2019. [CrossRef]

70. Michalos, A.C.; Creech, H.; McDonald, C.; Kahlke, P.M. Knowledge, Attitudes and Behaviours. Concerning Education for Sustainable Development: Two Exploratory Studies. Soc. Indic. Res. 2011, 100, 391-413. [CrossRef] 